\title{
Correction to: Identifying Efficient Transport Pathways in Early-Wood Timber: Insights from 3D X-ray CT Imaging of Softwood in the Presence of Flow
}

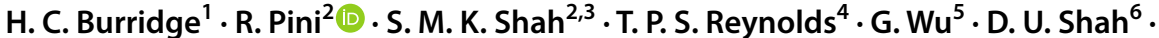 \\ O. A. Scherman ${ }^{5}$ M. H. Ramage ${ }^{6}$ P. F. Linden ${ }^{7}$
}

Published online: 16 March 2021

(C) The Author(s) 2021

\section{Correction to: Transport in Porous Media (2021) 136:813-830 https://doi.org/10.1007/s11242-020-01540-8}

The article "Identifying Efficient Transport Pathways in Early-Wood Timber: Insights from 3D X-ray CT Imaging of Softwood in the Presence of Flow", written by "H. C. Burridge, R. Pini, S. M. K. Shah, T. P. S. Reynolds, G. Wu, D. U. Shah, O. A. Scherman, M. H. Ramage and P. F. Linden”, was originally published Online First without Open Access. After publication in volume 136, issue 3, page 813-830 the author decided to opt for Open Choice and to make the article an Open Access publication. Therefore, the copyright of the article has been changed to (C) The Author(s) 2020 and the article is forthwith distributed under a Creative Commons Attribution 4.0 International License, which permits use, sharing, adaptation, distribution and reproduction in any medium or format, as long as you give appropriate credit to the original author(s) and the source, provide a link to the Creative Commons licence, and indicate if changes were made. The images or other third party material in this article are included in the article's Creative Commons licence, unless

The original article can be found online at https://doi.org/10.1007/s11242-020-01540-8.

R. Pini

r.pini@imperial.ac.uk

1 Department of Civil and Environmental Engineering, Imperial College London, London SW7 2AZ, UK

2 Department of Chemical Engineering, Imperial College London, London SW7 2AZ, UK

3 Present Address, UCL Mechanical Engineering, Research Complex At Harwell, RAL, Didcot OX11 0FA, Oxfordshire, UK

4 Institute for Infrastructure and Environment, School of Engineering, University of Edinburgh, Edinburgh EH9 3FG, UK

5 Melville Laboratory for Polymer Synthesis, Department of Chemistry, University of Cambridge, Lensfield Road, Cambridge CB2 1EW, UK

6 Department of Architecture, University of Cambridge, Cambridge CB2 1PX, UK

7 Department of Applied Mathematics and Theoretical Physics, Centre for Mathematical Sciences, University of Cambridge, Wilberforce Road, Cambridge CB3 0WA, UK 
indicated otherwise in a credit line to the material. If material is not included in the article's Creative Commons licence and your intended use is not permitted by statutory regulation or exceeds the permitted use, you will need to obtain permission directly from the copyright holder. To view a copy of this licence, visit https://creativecommons.org/licen ses/by/4.0. The original article has been corrected.

Open Access This article is licensed under a Creative Commons Attribution 4.0 International License, which permits use, sharing, adaptation, distribution and reproduction in any medium or format, as long as you give appropriate credit to the original author(s) and the source, provide a link to the Creative Commons licence, and indicate if changes were made. The images or other third party material in this article are included in the article's Creative Commons licence, unless indicated otherwise in a credit line to the material. If material is not included in the article's Creative Commons licence and your intended use is not permitted by statutory regulation or exceeds the permitted use, you will need to obtain permission directly from the copyright holder. To view a copy of this licence, visit http://creativecommons.org/licenses/by/4.0/.

Publisher's Note Springer Nature remains neutral with regard to jurisdictional claims in published maps and institutional affiliations. 